\title{
Anna Janowicz, Piotr Krakowiak, Agnieszka Paczkowska, Barba- ra Sikora, Zdrowa rozmowa. Sztuka komunikacji z osobami u kresu życia i ich opiekunami, Gdańsk: Fundacja Hospicyjna, 2014, s. 216.
}

DOI: http://dx.doi.org/10.12775/PCh.2016.039

Problemy i oczekiwania osób u kresu życia oraz ich opiekunów coraz częściej stanowią przedmiot głębokich analiz naukowych. Podejmują je nie tylko specjaliści w dziedzinach nauk medycznych, nauk o zdrowiu, ale też nauk społecznych i teologicznych. Wspólne dla podjętych już refleksji są poszukiwania odpowiedzi na ważne pytania o sposoby radzenia sobie w sytuacji przewlekłej choroby, niepełnosprawności, niesamodzielności bliskiego czy wobec jego umierania. W owych poszukiwaniach uczestniczą zarówno profesjonalni, jak i nieformalni opiekunowie, którzy zgodnie potwierdzają, że $\mathrm{w}$,codziennym trudzie sprawowania opieki i wykonywania czynności pielęgnacyjno-leczniczo-socjalnych pożądane są zdolności nawiązywania relacji z cierpiącym człowiekiem i jego bliskimi" (s. 9). O ile najnowsze dostępne rozwiązania medyczne czy organizacyjne dają ukojenie w codziennym trudzie, tak wciąż nie została zaspokojona podstawowa potrzeba chorego i jego opiekunów, jaką jest właściwa komunikacja. W perspektywie pracy $\mathrm{z}$ chorymi i ich najbliższym otoczeniem okazuje się niełatwą umiejętnością. Jakie czynniki decydują o prowadzeniu mądrej rozmowy? Jakie wartości są istotne dla właściwej komunikacji? W jaki sposób komunikować się z chorym, aby zapewnić mu poczucie godnego odchodzenia? Na te pytania odpowiadają autorzy książki pod tytułem: Zdrowa rozmowa. Sztuka komunikacji z osobami u kresu życia i ich opiekunami.

Recenzowana książka jest wyjątkowa pod kilkoma względami. Zebrane w niej refleksje skupione wokół takich kategorii, jak: choroba, cierpienie, umieranie, opisy trudnych sytuacji czy praktyczne wskazówki, doskonale odpowiadają na potrzeby osób poszukujących konkretnych rozwiązań w zakresie wsparcia osób niesamodzielnych. Kolejnym walorem opracowania jest skupienie wokół problematyki opieki nad osobami u kresu życia autorów o różnorodnych doświadczeniach, którzy zechcieli podzielić się profesjonalną i praktyczną wiedzą. Bez wątpienia ogromny wkład w tak przygotowaną książkę ma wydawca - Fundacja Hospicyjna ${ }^{1}$ - która od 2004

${ }^{1}$ Na uwagę zasługują także inne opracowania: Piotr Krakowiak, Dominik Krzyżanowski, Aleksandra Modlińska, Przewlekle chory w domu. Poradnik dla rodzin i opiekunów 
roku podejmuje działania o charakterze edukacyjnym i społecznym na rzecz poprawy jakości życia osób u kresu życia oraz ich rodzin. Autorzy Zdrowej rozmowy przekazali spójny i przemyślany projekt - pomysł na prowadzenie skutecznej i wzmacniającej rozmowy nie tylko dla profesjonalnych, ale i nieformalnych opiekunów z ich podopiecznymi.

Fundamentem procesu wsparcia osób u kresu życia jest zdolność nawiązywania relacji o charakterze terapeutycznym z chorym, ale i jego bliskimi. Jak podkreślają autorzy poradnika, właściwa komunikacja jest dopełnieniem procesu leczenia, a podnoszenie umiejętności w tym zakresie wydaje się „właściwą drogą do aktywności zawodowej osób profesjonalnie zajmujących się chorymi” (s. 9). Budowanie relacji pacjent-członek zespołu terapeutycznego jest trudne, szczególnie z uwagi na zróżnicowany stopień rozwoju umiejętności komunikacyjnych czy możliwości adaptacyjnych w chorobie (s. 10). Dlatego istotne w komunikacji staje się poznanie potrzeb podopiecznego, jego ograniczeń fizycznych, psychicznych i społecznych, które sprzyja rozumieniu ciężko chorego. W jaki sposób zachować się w sytuacji przewlekłej choroby, możemy dowiedzieć się z pierwszego rozdziału książki zatytułowanego Nawiazywanie relacji i budowanie zaufania z chorym u kresu życia. Szczególną uwagę warto poświęcić na poznanie czynników - zarysowanych przez autorów w modelu komunikacji interpersonalnej - warunkujących skuteczną komunikację, która bez względu na miejsce sprawowanej opieki, pielęgnacji, leczenia czy rehabilitacji człowieka u kresu życia, powinna przebiegać według określonych zasad (s. 16-18). Celem refleksji zebranych w tym rozdziale jest przede wszystkim uświadomienie czytelników o mnogości czynników, które wpływają na komunikowanie się, jak kontekst fizyczny i sytuacyjny, ale też komunikaty werbalne i pozawerbalne oraz pierwsze minuty kontaktu $\mathrm{z}$ chorymi i jego bliskimi. Zebrane w pierwszym rozdziale książki rozważania zostały opatrzone licznymi przykładami komunikowania się opiekunów z ich pacjentami oraz cennymi wskazówkami metodycznymi, w tym wypadku opartymi na technikach aktywnego słuchania (potwierdzenie odbioru informacji, uściślenie wypowiedzi, parafrazowanie i odzwierciedlenie uczuć) (s. 35) i podstawowych wartościach, jak: godność,

(Gdańsk: Fundacja Hospicyjna, 2012); Józef Binnebesel, Zbigniew Bohdan, Piotr Krakowiak, Dominik Krzyżanowski, Agnieszka Paczkowska, Alicja Stolarczyk, Przewlekle chory w domu. Poradnik dla rodziny i opiekunów (Gdańsk: Fundacja Hospicyjna, 2012); Piotr Krakowiak, Wolontariat w opiece u kresu życia. Geneza, rozwój, funkcjonowanie, możliwości optymalizacji i integracji ku syntezie socjopedagogicznej (Gdańsk: Fundacja Hospicyjna, 2012). 
szacunek i empatia. Warto przy tym zaznaczyć, że proces wspierania osób u kresu życia uzależniony jest od ich stanu emocjonalnego i poziomu motywacji, co ma szczególne znaczenie w sytuacjach, kiedy trzeba przekazać informacje o chorobie zmierzającej ku śmierci. W jaki sposób przejść przez ostatnie stadium choroby i jak organizować opiekę paliatywno-hospicyjną, możemy dowiedzieć się z drugiego rozdziału poradnika. Mimo że Polska znajduje się wśród krajów, które charakteryzuje najwyższy poziom rozwoju opieki hospicyjnej w Europie, to wciąż brakuje przede wszystkim rozwiązań systemowych, które umożliwiłyby wdrożenie idei opieki paliatywnej zdefiniowanej przez Światową Organizację Zdrowia (WHO). Opieka paliatywna czy paliatywno-hospicyjna zakłada holistyczne podejście do opieki nad chorym i jego rodziną, a za cel stawia poprawę jakości ich życia², uwzględniając aspekt fizyczny, psychosocjalny i duchowy. W rozdziale drugim znajdziemy zatem odpowiedzi między innymi na takie pytania: w jaki sposób przekazać informację o chorobie zmierzającej ku śmierci?; kto powinien tę informację przekazać i jak współpracować z chorym na tym etapie opieki? Czytelnicy odnajdą propozycje konkretnych pytań, które mogą bezpośrednio wdrożyć do codziennej praktyki i ułatwią im przeprowadzenie rozmowy. Muszą przy tym pamiętać, że przekazywanie informacji jest procesem, a zatem towarzyszyć temu winno słuchanie pełne empatii, połączone ze zrozumieniem istotnych potrzeb chorego, współpraca z rodziną i pozytywny obraz pomocy hospicyjnej (s. 62).

Trzeci rozdział poradnika został poświęcony relacjom w zaawansowanej fazie choroby. Autorzy poddali analizie procesy nieprzystosowania i adaptacji chorego oraz jego bliskich do zbliżającej się śmierci, słusznie przy tym zauważając, że „opieka nad pacjentem w zaawansowanej fazie choroby nie jest pojedynczą rozmową i obejmuje wiele wydarzeń, w których chory i jego bliscy mają swój udział" (s. 84). Dlatego ta faza wspierania chorego i jego rodziny powinna zostać poddana analizie, uwzględniającej problemy czy potrzeby fizyczne, emocjonalne oraz duchowe. Autorzy poradnika i tu wychodzą naprzeciw czytelnikowi, proponując konkretne rozwiązania - strategie np. radzenia sobie ze stresem, pytania o emocje, sposoby zachowania w stosunku do chorego, uwzględniając przy tym medyczne i pozamedyczne aspekty pomocy w różnych wymiarach cierpienia chorego. Autorzy wska-

${ }^{2}$ Por. Tomasz Buss, Monika Lichodziejewska-Niemierko, „Opieka paliatywna w Polsce - od idei do praktyki (również lekarza rodzinnego)", Forum Medycyny Rodzinnej 4 (2008): 277-285; Piotr Krakowiak, Zdą̇yć z prawda. O sztuce komunikacji w hospicjum (Gdańsk: Fundacja Hospicyjna, 2006). 
zują także, że istotne w pomocy paliatywno-hospicyjnej na tym etapie jest dostosowanie pomocy do poziomu stresu i stanu emocjonalnego chorego przez wszystkich członków zespołu, w tym opiekunów rodzinnych i wolontariuszy (s. 103).

Podstawą dla sformułowanych przez autorów poradnika w rozdziale czwartym refleksji jest kategoria nadziei i jej znaczenia w opiece nad osobami u kresu życia. Odwołując się do własnych doświadczeń, pokusili się o sformułowanie tezy, że nadzieja - w obliczu nieuchronnej śmierci - staje się „rodzajem ochrony psychicznej, rodzajem wewnętrznego źródła mocy w zmaganiu się z trudnościami” (s. 125). Źródłami nadziei zaś są duchowość i religijność. Odwołując się w profesjonalnej pomocy osobom u kresu życia do przytoczonych przez autorów poradnika kategorii, można oczekiwać, że współpraca pomiędzy personelem a chorymi będzie sprawniejsza, natomiast jakość życia chorych i ich opiekunów wzrośnie. Łatwiej także będzie poszukiwać odpowiedzi na pytania: w jaki sposób dodawać otuchy choremu?; na jakich podstawach zbudować przestrzenie nadziei?; jaką nadzieję mogą u ciężko chorego wspierać opiekunowie i bliscy? (s. 126).

W kolejnym rozdziale szczegółowo przeanalizowano zagadnienia opieki w ostatnich dniach i godzinach życia chorego. Profesjonalni i nieformalni opiekunowie poznają główne symptomy ostatnich godzin życia chorego i wskazówki, jak postępować w sytuacji odchodzenia najbliższych. Komunikacja $\mathrm{z}$ umierającym powinna opierać się na tym etapie na okazywaniu troski, towarzyszeniu, reagowaniu na wszystkie potrzeby chorego (s. 147). Nieocenione zdają się być te przykłady opisane przez autorów, które w sytuacji odchodzenia chorych są nieuniknione. Cenne są także wskazówki ukierunkowane na najbliższe otoczenie osoby umierającej, uwzględniające ich potrzeby (w tym potrzebę rozwoju osobistego), ale też koszty emocjonalnoduchowe, które ponoszą w trakcie opieki nad chorymi. Piąta część poradnika skupiona jest wokół refleksji nad zachowaniem bliskich, ich emocjami oraz wokół sposobów radzenia sobie w sytuacji odzyskiwania sił do pracy i życia, które autorzy poradnika oparli na triadzie: edukacji, wsparciu i duchowości.

Szósty rozdział został poświęcony problematyce zmęczenia pomaganiem oraz metodom wspomagającym profesjonalnych opiekunów w odzyskiwaniu sił do współpracy z chorym i metodom wspierania opiekunów nieformalnych czy pomocy opiekunom rodzinnym w przeżywaniu straty i procesu żałoby.

Niewątpliwym atutem książki są także dodatki, z których pierwszy wprowadza do zagadnień dotyczących opieki nad osobami u kresu życia i przybliża podstawowe pojęcia, jak opieka u kresu życia, opieka paliatywno- 
-hospicyjna, opieka długoterminowa czy zespół opiekuńczy. Drugi stanowi opis poszczególnych stanów ego uczestników komunikacji interpersonalnej według teorii analizy transakcyjnej. Czytelnik zapozna się między innymi z charakterystyką konkretnych postaw (stanu ego „Rodzina”, „Dziecko”, „Dorosły”) i zasadami komunikacji Berne'a. Pomocne w komunikacji okaże się także rozumienie znaczenia gier terapeutycznych, poznanie modelu czterowymiarowej struktury nadawania komunikatu autorstwa Schulza von Thuna, który pozwoli zgłębić wiedzę w zakresie procesów zachodzących pomiędzy pacjentem a opiekunem, a także poznanie modelu czterowymiarowej struktury odbioru komunikatu.

Zdrowa rozmowa. Sztuka komunikacji z osobami u kresu życia to obowiązkowa lektura nie tylko dla profesjonalnych i nieformalnych opiekunów osób u kresu życia, ale dla wszystkich, dla których troska, empatia, szacunek, godność i życie są najwyższymi wartościami. Zaprezentowane w poradniku problemy z pewnością nie zostały wyczerpane, bowiem system wsparcia osób u kresu życia i ich rodzin wciąż wymaga podejmowania naukowych poszukiwań i formułowania praktycznych rozwiązań. Jednak na tym etapie książka wprowadzi nie tylko osoby profesjonalnie zajmujące się wsparciem osób chorych w tajemnice nieuchronnej śmierci.

Katarzyna Kuziak*

\section{Bibliografia}

Buss, Tomasz, Monika Lichodziejewska-Niemierko. „Opieka paliatywna w Polsce od idei do praktyki (również lekarza rodzinnego)". Forum Medycyny Rodzinnej 4 (2008): 277-285.

Krakowiak, Piotr, Dominik Krzyżanowski, Aleksandra Modlińska. Przewlekle chory w domu. Poradnik dla rodzin i opiekunów. Gdańsk: Fundacja Hospicyjna, 2012.

Binnebesel, Józef, Zbigniew Bohdan, Piotr Krakowiak, Dominik Krzyżanowski, Agnieszka Paczkowska, Alicja Stolarczyk. Przewlekle chory w domu. Poradnik dla rodziny i opiekunów. Gdańsk: Fundacja Hospicyjna, 2012.

* Dr Katarzyna Kuziak jest adiunktem w Katedrze Pracy Socjalnej na Wydziale Nauk Pedagogicznych Uniwersytetu Mikołaja Kopernika w Toruniu. Adres: Wydział Nauk Pedagogicznych UMK, ul. Lwowska 1,87-100 Toruń; e-mail: kkuziak@umk.pl. 
Krakowiak, Piotr. Wolontariat w opiece u kresu życia. Geneza, rozwój, funkcjonowanie, możliwości optymalizacji i integracji ku syntezie socjopedagogicznej. Gdańsk. Fundacja Hospicyjna, 2012.

Krakowiak, Piotr. Zdażyć z prawdą. O sztuce komunikacji w hospicjum. Gdańsk: Fundacja Hospicyjna, 2006. 
